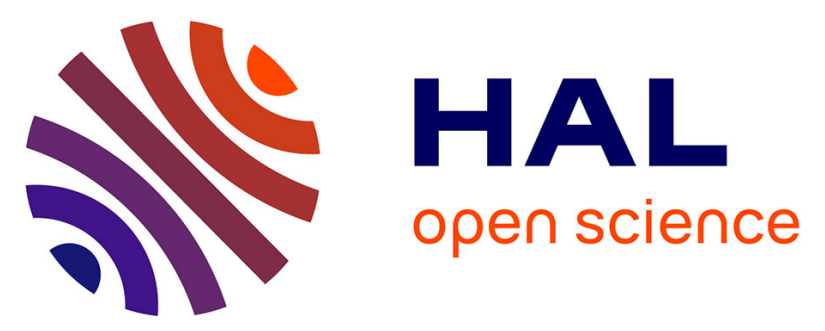

\title{
Severe Viral Hepatitis in a Patient with Chronic Lymphocytic Leukemia (CLL) Complicated with Autoimmune Haemolytic Anemia (AIAH), Treated with Steroids
}

Corentin Orvain, Alexandra Ducancelle, Caroline Eymerit-Morin, Marie-Christine Rousselet, Frederic Oberti, Mathilde Hunault-Berger, Aline Schmidt

\section{- To cite this version:}

Corentin Orvain, Alexandra Ducancelle, Caroline Eymerit-Morin, Marie-Christine Rousselet, Frederic Oberti, et al.. Severe Viral Hepatitis in a Patient with Chronic Lymphocytic Leukemia (CLL) Complicated with Autoimmune Haemolytic Anemia (AIAH), Treated with Steroids. Journal of Clinical Virology, 2015, 62, pp.26. 10.1016/j.jcv.2014.11.013 . inserm-03402266

\section{HAL Id: inserm-03402266 https://www.hal.inserm.fr/inserm-03402266}

Submitted on 25 Oct 2021

HAL is a multi-disciplinary open access archive for the deposit and dissemination of scientific research documents, whether they are published or not. The documents may come from teaching and research institutions in France or abroad, or from public or private research centers.
L'archive ouverte pluridisciplinaire HAL, est destinée au dépôt et à la diffusion de documents scientifiques de niveau recherche, publiés ou non, émanant des établissements d'enseignement et de recherche français ou étrangers, des laboratoires publics ou privés. 


\section{Infection}

\section{SEVERE VIRAL HEPATITIS IN A PATIENT WITH CHRONIC LYMPHOCYTIC LEUKAEMIA (CLL) COMPLICATED WITH AUTOIMMUNE HAEMOLYTIC ANEMIA (AIAH), TREATED WITH STEROIDS \\ --Manuscript Draft--}

\begin{tabular}{|c|c|}
\hline \multicolumn{2}{|l|}{ Manuscript Number: } \\
\hline Full Title: & $\begin{array}{l}\text { SEVERE VIRAL HEPATITIS IN A PATIENT WITH CHRONIC LYMPHOCYTIC } \\
\text { LEUKAEMIA (CLL) COMPLICATED WITH AUTOIMMUNE HAEMOLYTIC ANEMIA } \\
\text { (AIAH), TREATED WITH STEROIDS }\end{array}$ \\
\hline Article Type: & Case Report \\
\hline Keywords: & $\begin{array}{l}\text { autoimmune hemolytic anemia (AIAH); chronic lymphocytic leukemia (CLL); viral } \\
\text { hepatitis }\end{array}$ \\
\hline Corresponding Author: & $\begin{array}{l}\text { Aline Tanguy-Schmidt } \\
\text { FRANCE }\end{array}$ \\
\hline \multicolumn{2}{|c|}{$\begin{array}{l}\text { Corresponding Author Secondary } \\
\text { Information: }\end{array}$} \\
\hline \multicolumn{2}{|c|}{ Corresponding Author's Institution: } \\
\hline \multicolumn{2}{|c|}{$\begin{array}{l}\text { Corresponding Author's Secondary } \\
\text { Institution: }\end{array}$} \\
\hline Corresponding Author E-Mail: & alschmidt@chu-angers.fr \\
\hline First Author: & Corentin Orvain \\
\hline \multicolumn{2}{|c|}{ First Author Secondary Information: } \\
\hline \multirow[t]{7}{*}{ Order of Authors: } & Corentin Orvain \\
\hline & Alexandra Ducancelle \\
\hline & Caroline Eymerit-Morin \\
\hline & Marie-Christine Rousselet \\
\hline & Frederic Oberti \\
\hline & Mathilde Hunault-Berger \\
\hline & Aline Tanguy-Schmidt \\
\hline \multicolumn{2}{|c|}{ Order of Authors Secondary Information: } \\
\hline Abstract: & $\begin{array}{l}\text { Infectious complications are a major cause of morbidity and mortality in patients with } \\
\text { chronic lymphocytic leukaemia (CLL) due to impaired immunity secondary to the } \\
\text { disease itself and to the immunosuppressive therapies administered to these patients. } \\
\text { We report a 78-year old woman with CLL who was treated with steroids for } \\
\text { autoimmune hemolytic anemia (AIAH). A few weeks later, she was admitted for severe } \\
\text { acute hepatitis with disseminated intravascular coagulation (DIC). Despite the } \\
\text { symptomatic treatment of DIC, standard reanimation and probabilistic antibiotics, the } \\
\text { patient died within } 24 \text { hours with severe hepatic failure. Autopsy was in favor of a } \\
\text { disseminated viral infection with oesophageal, hepatic and pulmonary cytopathologic } \\
\text { lesions with acidophilic intranuclear inclusions suggestive of herpes virus, even though } \\
\text { HSV } 1 \text { and 2, CMV and HHV6 PCRs were negative. This case of severe viral hepatitis } \\
\text { with oesophagitis occurring three weeks after the introduction of high-dose steroid } \\
\text { treatment for AlHA in a CLL patient calls for anti-herpetic prophylaxis in such patients, } \\
\text { immunodepressed by their diseases and the treatment they receive. }\end{array}$ \\
\hline Author Comments: & \\
\hline
\end{tabular}




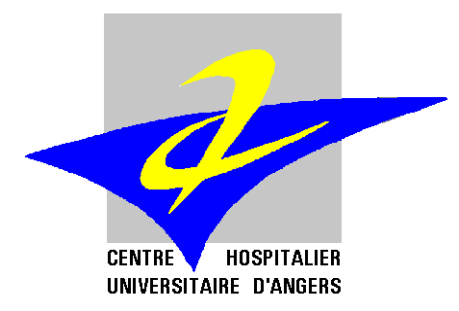

Maladies du sang

UNIVERSITAIRE D'ANGERS

Angers, 03/2013, the $14^{\text {th }}$

\section{Doctor Aline Tanguy-Schmidt}

\section{Editor in chief \\ Infection}

Dear Editor,

You will find enclosed a manuscript entitled:

\section{«Severe viral hepatitis in a patient with chronic lymphocytic leukemia (CLL) complicated with autoimmune haemolytic anemia (AIAH), treated with steroids »}

by Corentin Orvain, Alexandra Ducancelle, Caroline Eymerit-Morin, Marie-Christine Rousselet, Frederic Oberti, Mathilde Hunault-Berger, and Aline Tanguy-Schmidt that we submit as an original article in Infection.

All authors concur with the submission of this manuscript, they have reviewed and approved for the final version of the manuscript. All authors will sign a statement attesting authorship, disclosing all potential conflict of interest, and releasing the copyright should the manuscript be available for publication.

The article is original, does not infringe upon any copyright or other proprietary right of any third party, is not under consideration by another journal, and has not been previously published.

Looking forward to hearing from you,

Sincerely yours. 
Authors: ORVAIN C [1,2], DUCANCELLE A [1,3], EYMERIT-MORIN C [1,4], ROUSSELET MC [1,4], OBERTI $\mathrm{F}[1,5]$, HUNAULT-BERGER M $[1,2,6]$, TANGUY-SCHMIDT A $[1,2,6]$

[1] LUNAM Université, Angers, France.

[2] CHU Angers, Service des Maladies du Sang, Angers, France.

[3] CHU Angers, Laboratoire de virologie, Angers, France.

[4] CHU Angers, Département de pathologie cellulaire et tissulaire, Angers, France.

[5] CHU Angers, Service d'hépato-gastroentérologie, Angers, France.

[6] INSERM U892

Corresponding author:

Dr. Tanguy-Schmidt

CHU d’Angers, 4 rue Larrey, 49933 Angers Cedex 9, France.

Phone number: +33 (0) 2413544 72. Fax: +33 (0) 241355381 .

E-mail address: alschmidt@chu-angers.fr

Funding source(s): none

Conflict of interest: none

Article type: Case report

Word count: 1565

Running title: Severe viral hepatitis in a CLL patient. 


\section{Abstract:}

Infectious complications are a major cause of morbidity and mortality in patients with chronic lymphocytic leukaemia (CLL) due to impaired immunity secondary to the disease itself and to the immunosuppressive therapies administered to these patients. We report a 78-year old woman with CLL who was treated with steroids for autoimmune hemolytic anemia (AIAH). A few weeks later, she was admitted for severe acute hepatitis with disseminated intravascular coagulation (DIC). Despite the symptomatic treatment of DIC, standard reanimation and probabilistic antibiotics, the patient died within 24 hours with severe hepatic failure. Autopsy was in favor of a disseminated viral infection with oesophageal, hepatic and pulmonary cytopathologic lesions with acidophilic intranuclear inclusions suggestive of herpes virus, even though HSV 1 and 2, CMV and HHV6 PCRs were negative. This case of severe viral hepatitis with oesophagitis occurring three weeks after the introduction of high-dose steroid treatment for AIHA in a CLL patient calls for anti-herpetic prophylaxis in such patients, immunodepressed by their diseases and the treatment they receive.

Keywords: autoimmune hemolytic anemia (AIAH) ; chronic lymphocytic leukemia (CLL) ; viral hepatitis 


\section{Introduction:}

Infections complications are a major cause of morbidity and mortality in patients with chronic lymphocytic leukaemia (CLL) due to impaired immunity secondary to the disease itself (T-cell dysfunction, hypogammaglobulinemia), with bacterial infections and herpes virus reactivation being the most frequent [1][2]. The introduction of immunosuppressive therapy has led to the breakthrough of opportunistic infections, especially viral infections [1][2]. We report herein the case of a patient with CLL, who developed a severe viral hepatitis a few weeks after receiving steroid therapy for the treatment of autoimmune haemolytic anaemia (AIHA).

\section{Case report:}

A 78 year-old female patient with arterial hypertension and moderate hypertension-related chronic renal insufficiency was diagnosed with chronic lymphocytic leukaemia (CLL) in 2002. Diagnosis was made after exploration of lymphocytosis with lymphocyte immunophenotyping in favour of CLL with no indication for treatment, as the disease had no clinical repercussion. Disease re-evaluation was considered in 2006. At this time, there was still a lymphocyte B clone with a 4-point Matutes score: CD5 100\%, CD23 100\%, weak CD22 expression, FMC7 37\% with a weak expression of a kappa surface immunoglobulin. There were no specific karyotypic features, with especially no $17 \mathrm{p} 13$ deletion. The patient had a positive direct Coombs test with no signs of hemolysis ( $\mathrm{G}$ immunoglobulin autoantibody with no specific characteristics found after elution). Serum protein electrophoresis showed no hypogammaglobulinemia. During the follow-up, progressive anemia with no signs of hemolysis made CLL treatment necessary, and so, chlorambucil was introduced, starting September 2009.

The patient was admitted in December 2009 for rapid aggravation of anemia which was poorly tolerated. Hemoglobin levels were at $5.5 \mathrm{~g} / \mathrm{dL}$, and anemia was normocytic (92.7fL) and aregenerative (reticulocyte count was $39 \mathrm{G} / \mathrm{L}$ ), with newly hemolytic features with unconjugated bilirubin at $37 \mu \mathrm{mol} / \mathrm{L}$ and lactate dehydrogenase at $484 \mathrm{UI} / \mathrm{L}$ with an upper reference limit at 360 
$\mathrm{UI} / \mathrm{L}$ (those values were normal six months earlier). There was a normal haptoglobin at 0.9 and

elevated ferritin at $2157 \mu \mathrm{g} / \mathrm{L}$ in this context of hemolysis, with normal aminotransferase levels and without inflammation. There was no other cytopenia and there was no schizocytosis. The same positive direct Coombs test was found with a $\mathrm{G}$ immunoglobulin autoantibody, with no specific characteristics found after elution. To maintain an acceptable hemoglobin level, the transfusion of 5 units of packed red blood cells in three days was necessary.

With the hypothesis of iatrogenic medullar aplasia, chlorambucil treatment was interrupted. Also, the occurrence of an autoimmune hemolytic anemia calls for introduction of steroid therapy (prednisone $1 \mathrm{mg} / \mathrm{kg} /$ day). No aggressive immunochemotherapy could be administered to treat a hypothetical CLL medullar involvement due to the patient's age and concomitant medical conditions. Nevertheless, the rapid response of anemia to steroids allowed for discharge of the patient. Three weeks later, the patient was admitted to the emergency department for acute abdominal pain and diffuse ecchymosis. She had neither fever nor hemodynamic failure. No additional clinical features were found. She had newly marked aminotransferase increase, with aspartate aminotransferase (ASAT) up to $336 \mathrm{UI} / \mathrm{L}(\mathrm{N}<37)$ and ALAT up to $247 \mathrm{UI} / \mathrm{L}(\mathrm{N}<43)$ associated with coagulation disorders (platelet count $18 \mathrm{G} / \mathrm{L}$, prothrombin time (PT) $20 \%$, fibrinogen $<0,30 \mathrm{~g} / \mathrm{L}$ with soluble complexes and D-dimer index between 16 and 32) with serum albumin at $46 \mathrm{~g} / \mathrm{L}$ and normal serum bilirubin in favor of overt disseminated intravascular coagulation (DIC). There was no renal function aggravation. Lactate dehydrogenase was at seven times the upper reference limit (2904 $\mathrm{UI} / \mathrm{L}$ ) and serum ferritin was at $481 \mu \mathrm{g} / \mathrm{L}$. Normocytic aregenerative (reticulocytes: $60 \mathrm{G} / \mathrm{L}$ ) and hemolytic (haptoglobin: <0.2) anemia was present.

The hepatic echosonography was normal; inferior vena cava, sus-hepatic and portal veins were permeable. Renal veins were also permeable. Abdominal scanning did not reveal any abnormalities either, including no sign of mesenteric ischemia or tumor. Hepatic parenchyma and intra and extrabiliary ducts were normal. The bone marrow exploration was poor, with important cellular lysis. 
There were rare mast cells, no blasts and no signs in favor of haemophagocytic syndrome. By

Despite symptomatic treatment of the disseminated intravascular coagulation, standard reanimation and probabilistic antibiotics, the patient died within 24 hours with severe hepatic failure (PT 5\%). Autopsy was performed and showed a steatosic liver without ascites or peritonitis and many punctiform oesophageal ulcerations. The other abdominal or thoracic organs did not show any abnormalities. Hepatic parenchyma architecture was normal with portal spaces filled with a mild mononuclear inflammatory infiltrate. Macro-vesicular steatosis was confirmed, associated with patchy acidophilic hepatocellular necrosis, without cellular inflammation. Next to these necrotic foci, altered hepatocytes displayed abnormal nuclei with a thick nuclear membrane, margination of chromatin and a large vitreous acidophilic inclusion (figure 1). Some of these altered hepatocytes were giant and multi-nucleated, with multiple acidophilic inclusions (figure 2). Similar nuclear inclusions were found in the epidermoid cells next to the oesophageal mucosae ulcerations and in rare pneumocytes. Splenic and bone marrow tissues were infiltrated by small lymphocytes showing residual CLL. The final pathologic diagnosis was a disseminated viral infection with cytopathologic lesions suggestive of herpes virus. Immunohistochemical labelling was negative for type 1 Herpes Simplex Virus (HSV), adenovirus, and cytomegalovirus (CMV) on liver and oesophageal sections. Polymerase Chain Reactions (PCR) carried out on the oesophageal formalin-fixed tissue were negative for HSV 1 and 2, CMV and human herpes virus (HHV-6). Serology showed prior immunisation against HSV, CMV, Epstein-Barr virus (EBV) and varicella-zoster virus (VZV) and no viral hepatitis (hepatitis A: negative anti-HAV IgM, hepatitis B: vaccinee profile ; hepatitis C: negative anti-HCV) on the hospitalization day. No serological herpes virus reactivation could be investigated due to insufficient quantity of serum.

Even though intranuclear inclusions are the most distinctive feature for herpes virus infections, additional specific explorations could not prove the responsibility of herpes group virus. Still, for this patient, immunodepressed by her CLL, the treatment she received (chlorambucil, steroids), and the 
presence of severe hepatitis with DIC and herpes group like provoked lesions, enables at least the diagnosis of disseminated viral infection.

\section{Discussion:}

Herpes simplex virus (HSV) hepatitis is rare and accounts for only $1 \%$ of all acute liver failures. The importance of recognizing HSV-induced acute liver failure is based on its extremely severe clinical course with a near $75 \%$ lethality rate [3]. HSV hepatitis is just one of several clinical manifestations of HSV sepsis leading more frequently to encephalitis, pneumonia and esophagitis.

This hepatitis is often severe, sometimes fulminant, caused by immunosuppression, most commonly associated with defects in cell-mediated immunity, or immunosuppressing therapy, even administered for a short time [3]. Herpetic hepatitis has non-specific clinical features: fever occurs in $82 \%$ of the patients but can lack in case of immunosuppression, leucopenia and thrombopenia are frequent, and cytolysis is almost always present in typically anicteric patients [3]. Cutaneous lesions are very evocative of the diagnosis and should be investigated, but are not always present [4]. Diagnosis of herpetic hepatitis is based on the liver biopsy showing hemorrhagic necrosis of liver parenchyma, a reduced inflammatory infiltration and characteristic intranuclear viral inclusions. The herpes virus can be isolated by PCR in the blood stream or in cutaneous lesions if they exist. In immunocompetent patients, primo-infection is the most common whereas it is mostly viral reactivation in immunocompromised patients [4].

Infections in CLL patients, particularly bacterial, are one of the most pejorative factors, even in untreated patients. The incidence of moderate to severe infections ranges from 0.25 to 0.5 per patient-year [5]. These complications are due to alterations in immune functions including both qualitative and quantitative defects: T-cell dysfunction and hypogammaglobulinemia. Other defects involve NK cells, neutrophils, monocytes/macrophages and complement. Untreated patients especially encounter lower respiratory tract bacterial infections and herpes virus reactivation (Herpes 
Zoster Virus reactivation being the most frequent). Fungal and opportunistic infections are rare in untreated patients [2].

CLL patients are also exposed to infections due to immunosuppression from cytotoxic therapy and corticosteroids. As seen in our patient, the incidence of opportunistic infections is frequent in patients receiving steroids for the treatment of CLL-related AIHA, which worsens the state of immunodeficiency [6]. The recent introduction of immunosuppressive treatments including purine analogues such as fludarabine, and monoclonal antibodies such as rituximab and alemtuzumab adds the risk of opportunistic infections, especially viral infections [2]. Viral infections occur less often in patients receiving alkylating-based therapy than with the newer agents [7], or they occur in heavily pre-treated patients with advanced disease [8] [9]. In fludarabine-based regimens, besides the usual bacterial infections, the occurrence of numerous opportunistic diseases is due to the prolonged Tlymphocyte depletion (for up to two years after receiving treatment). These opportunistic diseases include Candida, mycobacterial and herpes virus infections [2]. Finally, patients receiving alemtuzumab are at high risk of cytomegalovirus (CMV) reactivation [10].

There are currently no standard guidelines for antimicrobial prophylaxis concerning CLL patients. Antiviral prophylaxis is mostly recommended during fludarabine-based therapies in elderly CLL patients with a low CD4 count [11]. Antimicrobial prophylaxis seems more controversial in younger untreated patients [12]. This remains a low-point in knowledge concerning infections in CLL patients as there are no control trials exploring antimicrobial prophylaxis in these patients. Also, in order to reduce infection rates, the use of low-dose intravenous immunoglobulin has been explored in patients with hypogammaglobulinemia, with a reduction in infection rates but no cost effectiveness [13].

In conclusion, this case of life-threatening viral infection, possibly from the herpes virus group, occurring in a CLL affected patient, brings up the question of efficient prophylaxis and, particularly, systematic anti-herpetic prophylaxis. 


\section{References:}

[1] Dearden C. Disease-specific complications of chronic lymphocytic leukemia. Hematology Am Soc Hematol Educ Program 2008: 450-6.

[2] Morrison VA. Infectious complications of chronic lymphocytic leukaemia: pathogenesis, spectrum of infection, preventive approaches. Best Pract Res Clin Haematol 2010; 23: 145-53.

[3] Kaufman B, Gandhi SA, Louie E, Rizzi R and Illei P. Herpes Simplex Virus hepatitis: case report and review. Clin Infect Dis 1997; 24 : 334-8.

[4] Bourliere M. Les hépatites virales non alphabétiques. FMC-HGE 2004.

[5] Molica S. Infections in chronic lymphocytic leukemia: risk factors, and impact on survival, and treatment. Leuk Lymphoma 1994; 13: 203-14.

[6] Mauro FR, Foa R, Cerretti R, et al. Autoimmune hemolytic anemia in chronic lymphocytic leukemia: clinical, therapeutic, and prognostic features. Blood 2000; 95: 2786-92.

[7] Morrison VA, Rai KR, Peterson BL, et al. Impact of therapy with chlorambucil, fludarabine, or fludarabine plus chlorambucil on infections in patients with chronic lymphocytic leukemia: Intergroup Study Cancer and Leukemia Group B 9011. J Clin Oncol 2001; 19: 3611-21.

[8] Hensel M, Kornacker M, Yammeni S, Egerer G, Ho AD. Disease activity and pretreatment, rather than hypogammaglobulinaemia, are major risk factors for infectious complications in patients with chronic lymphocytic leukaemia. Br J Haematol 2003; 122: 600-6.

[9] Molteni A, Nosari A, Montillo M, Cafro A, Klersy C, Morra E. Multiple lines of chemotherapy are the main risk factor for severe infections in patients with chronic lymphocytic leukemia with febrile episodes. Haematologica 2005; 90: 1145-7.

[10] Hillmen P, Skotnicki AB, Robak T et al. Alemtuzumab compared with chlorambucil as first-line treatment for chronic lymphocytic leukemia. J Clin Oncol 2007; 25: 5616-23.

[11] Shvidel L, Shtalrid M, Bairey O, et al. Conventionnal dose fludarabine-based regimens are effective but have excessive toxicity in elederly patients with refractory chronic lymphocytic leukemia. Leuk Lymphoma 2003; 44: 1947-50.

[12] Eichhorst BF, Busch R, Schweighofer C, Wendtner CM, Emmerich B and Hallek M. Due to low infection rates no routine anti-infective prophylaxis is required in younger patients with chronic lymphocytic leukemia during fludarabine-based first line therapy. Br J Haematol 2006; 136: 63-72.

[13] Molica S, Musto P, Chiurazzi F, et al. Prophylaxis against infections with low-dose intravenous immunoglobulins (IVIG) in chronic lymphocytic leukemia. Results of a crossover study. Haematologica 1996; 81: 121-126. 


\section{Click here to download high resolution image}
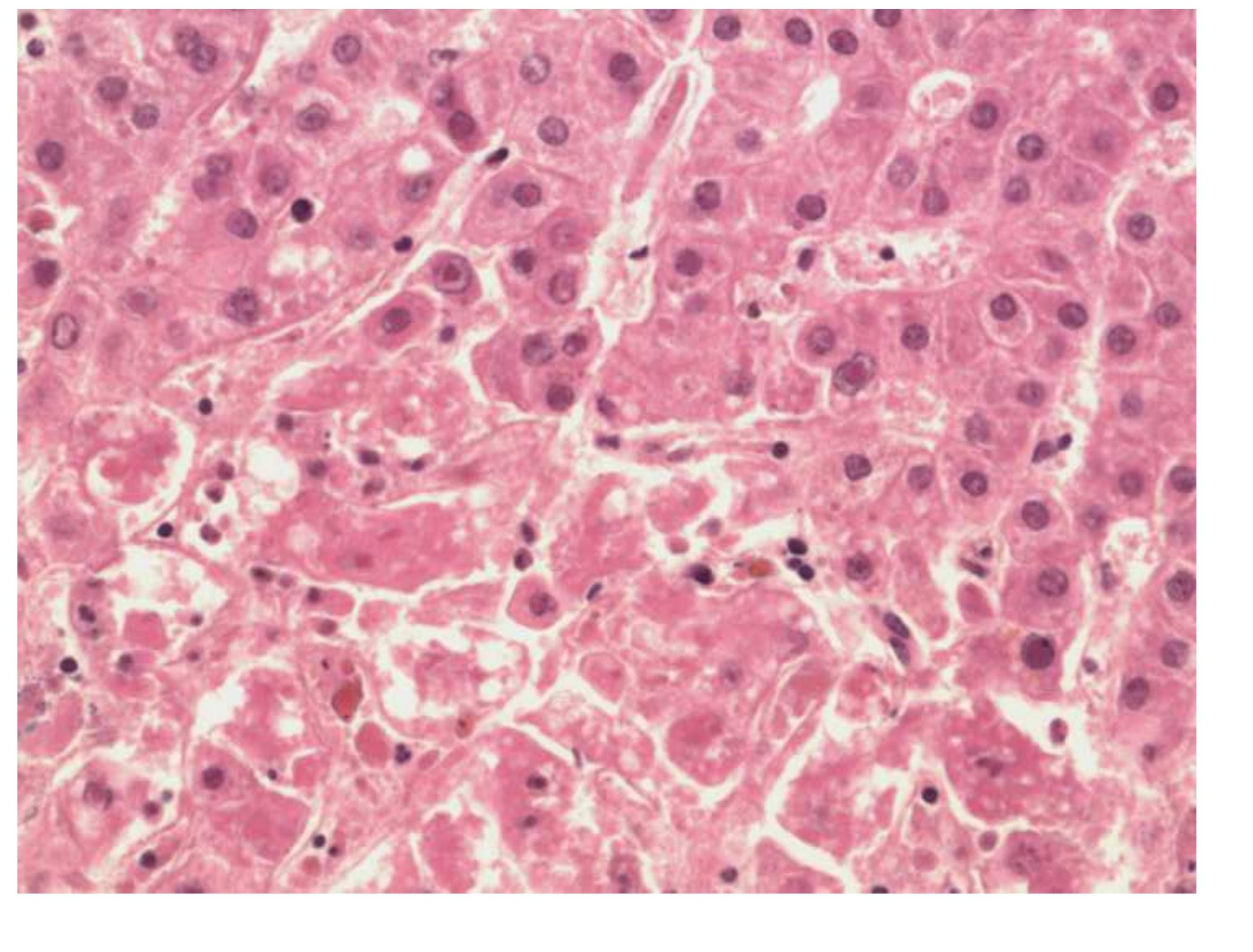
Click here to download high resolution image

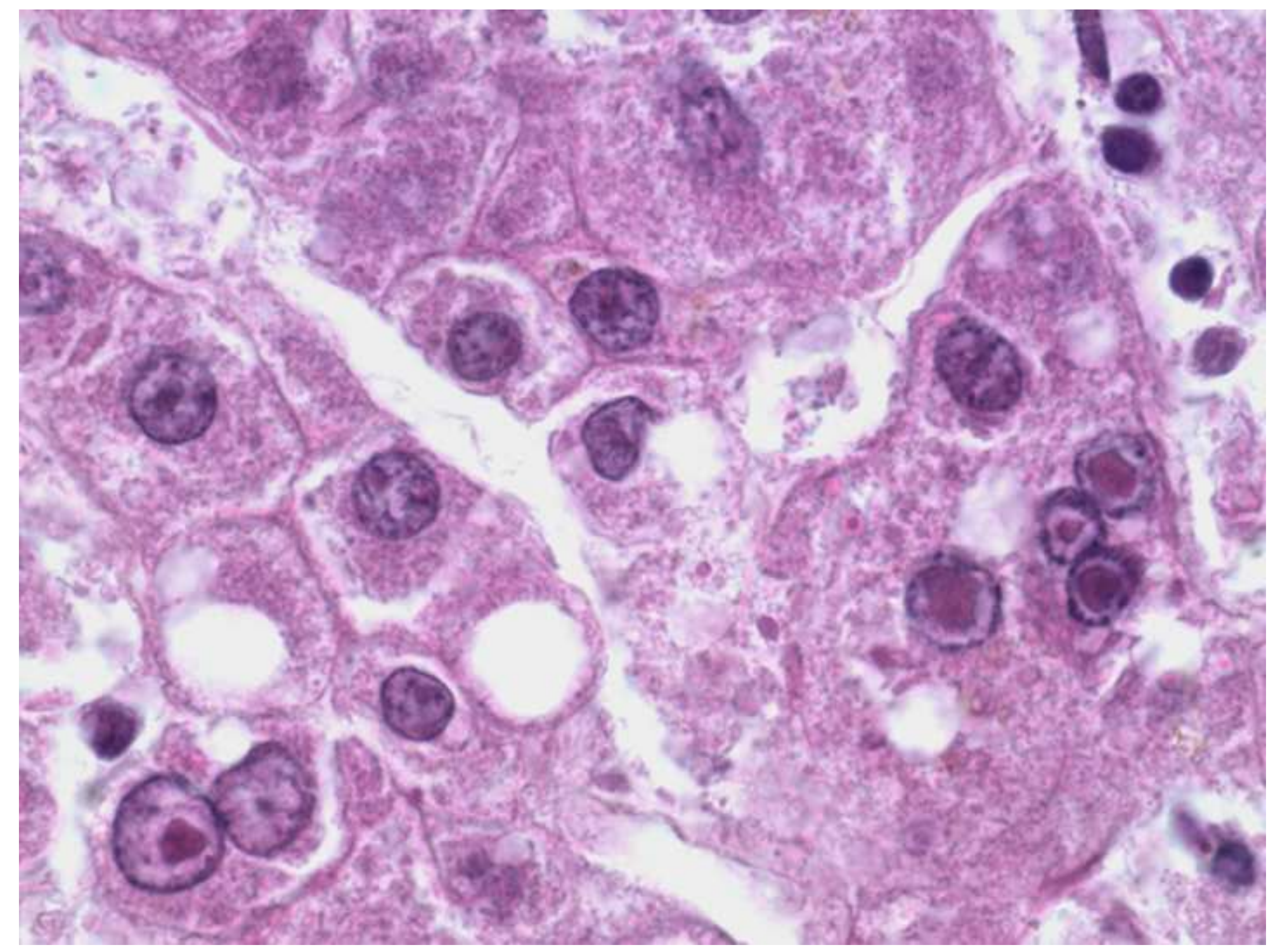


Electronic Supplementary Material
Click here to download Electronic Supplementary Material: Figure legends.docx 